MATRIK: JURNAL MANAJEMEN, STRATEGI BISNIS DAN KEWIRAUSAHAAN

Homepage: https://ojs.unud.ac.id/index.php/imbk/index

Vol. 15 No. 2, Agustus (2021), 277-288

\title{
The Effect Of E-Services On Customer Commitments Medied By The Trust Variable
}

\section{Nyoman Nurcaya}

${ }^{1}$ Fakultas Ekonomi dan Bisnis, Universitas Udayana

email: ichangnur@unud.ac.id

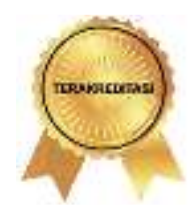

SINTA 2

\section{DOI : https://doi.org/10.24843/MATRIK:JMBK.2021.v15.i02.p10}

Customer commitment is one measure of the success of a company engaged in finance. Good service quality will increase customer commitment. Customers who have a high commitment will continue to carry out their financial transactions and inform others about the trust they get. This study aims to determine the impact of automated services (e-services) on customer commitment mediated by customer trust. This research was conducted at the Bali Regional Development Bank located in Denpasar - Bali. The sampling technique used is purposive sampling with a total sample of 90 customers. The data analysis technique used is Partial Least Square (PLS). The results of the analysis show that e-services have a significant positive effect on customer trust and customer loyalty. Customer trust has a significant positive effect on customer loyalty. Customer trust significantly mediates the effect of e-service on customer commitment.

Keywords: e-services. trust; commitment

\section{Pengaruh E-Layanan Terhadap Komitmen Pelanggan Dimediasi Oleh Variabel Kepercayaan}

\begin{abstract}
ABSTRAK
Komitmen pelanggan merupakan salah satu ukuran keberhasilan suatu perusahaan yang bergerak di bidang keuangan. Kualitas pelayanan yang baik akan meningkatkan komitmen pelanggan. Nasabah yang memiliki komitmen tinggi akan terus melakukan transaksi keuangannya dan menginformasikan kepada orang lain tentang kepercayaan yang diperolehnya. Penelitian ini bertujuan untuk mengetahui pengaruh layanan otomatis (e-services) terhadap komitmen pelanggan yang dimediasi oleh kepercayaan pelanggan. Penelitian ini dilakukan di Bank Pembangunan Daerah Bali yang berlokasi di Denpasar - Bali. Teknik pengambilan sampel yang digunakan adalah purposive sampling dengan jumlah sampel sebanyak 90 nasabah. Teknik analisis data yang digunakan adalah Partial Least Square (PLS). Hasil analisis menunjukkan bahwa eservices berpengaruh positif signifikan terhadap kepercayaan pelanggan dan loyalitas pelanggan. Kepercayaan pelanggan berpengaruh positif signifikan terhadap loyalitas pelanggan. Kepercayaan pelanggan secara signifikan memediasi pengaruh e-service terhadap komitmen pelanggan.
\end{abstract}

Kata kunci: layanan elektronik. memercayai; komitmen

\section{PRELIMINARY}

Competition in the business world, especially the business world engaged in banking services, is getting tougher. The number of financial institutions engaged in finance is increasing. The service products provided are also in tight competition in order to provide the best service for customers. The development of information technology plays a role in improving the quality of service to customers. Utilization of information technology means utilizing technology in data processing to facilitate the work of employees. Utilization of information technology includes (a) data processing, information processing, management 
systems and work processes electronically and (b) utilization of advances in information technology so that public services can be accessed easily and cheaply by the public (Nurcaya, 2018). Internet banking minimizes contact between financial service providers and customers (Angenu et al., 2015).

Service quality has become a dominant topic in service marketing (Hazra \& Srivastava, 2009). Service quality is a comparison between service expectations and service performance.(Valarie \& Leonard, 1988). One of the success factors of a bank as a service company is reflected in the ability of the bank to provide quality services. Service quality is a measure of how well the level of service provided is able to match what consumers expect (Tjiptono, 2012). These days, banks are using more and more automated services to achieve greater success in an increasingly dynamic environment. Companies must manage the level of quality of service they provide to their customers in order to increase profits and competitiveness. The quality of automated service has become a competitive weapon to compete. Automated service quality provides benefits for banks in terms of increasing service quality levels, increasing competitiveness, expanding market share, increasing innovation capabilities, and ultimately improving bank performance. (Al-hawari, 2011). Automated service quality outcomes (e-services) such as customer satisfaction and customer loyalty have received much attention in the literature (Johnston \& Kong, 2011).

Bank management should pay more attention to customer commitment. In addition to automated service quality, trustworthiness, and enjoyment, identifying other factors that contribute to overall customer commitment becomes very important. Other factors that can contribute to customer commitment include: the length of the relationship, the structure of the bond, and customer values (Al-hawari, 2011).

The previous descriptions show that building customer commitment or bank customers must receive constant attention through trust and improve service quality continuously. Customer desires are always changing, so is information technology. This study aims to determine how the effect of e-services on customer commitment mediated by the trust variable.

Review The literature that supports this research is the quality of automated services (e-services), building customer trust, and customer commitment.Service quality has been discussed in the service marketing literature as a comprehensive customer service assessment. Service quality is a comparison between customer expectations and customer perceptions (Parasuraman, Velarie, 1985; (Al-tamimi \& Hussein, 2006). Service quality is very important in a business that competes in the retail sector as well as in banking(Abdullah et al., 2011). Service quality in general is more emphasis on the word customer, service, quality and level or level. Service quality reflects all dimensions of product offerings that provide benefits for customers. Quality is the perfection of services carried out by service providers in meeting customer needs and desires and the accuracy of delivery to balance customer expectations. Service quality is an important thing that must be considered and maximized in order to be able to survive in an increasingly fierce competition. Growing consumer confidence in keeping customers loyal, is carried out by the company with various efforts. A comprehensive literature review and theory development found a formulation that trust is built on three dimensions, namely ability, kindness (benevolence), and integrity (integrity). These three dimensions are an important basis for building the trust of a consumer in order to trust a particular medium, transaction, or commitment. Trust, in the context of relationship marketing, is one of the dimensions to determine how far a party feels about the integrity and promises offered by the other party.(Istri Indriani \& Nurcaya, 2015). A study for e-services, trust is built by providing reliable services, with high integrity, and providing services that deliver on promises(Alhawari, 2011). 
Customer loyalty is to make continuous purchases from the company, increase business activities with the company in the future, and convey positive word of mouth (Xu et al., 2011). Loyalty isan attempt by customers to remain loyal with a strong awareness, impression of quality, trust and pride in a product, which is followed by repeat purchases. Loyal customers have the characteristics of making repeat purchases on a regular basis, buying between product and service lines, referring to others, showing immunity to the pull of competitors. Loyal customers will always make repeat purchases in the future if they need the same product or service. Indirectly, customer loyalty can increase the competitiveness of a company. Seeing the role of customer loyalty is very important for companies, many experts have conducted research on the important contribution of customer loyalty to companies.Commitment has been included in the literature as a very useful construct for measuring the probability of customer loyalty as well as estimating customer purchase intentions. Most researchers who study commitment build predictors to test their models in industrial markets as well as consumer goods (Al-hawari, 2011). This opinion provides a research gap on commitment to service products, especially banking.

Based on the literature review that has been discussed, it is important to conduct this research to determine the impact of e-services on customer trust and commitment, especially in the banking world. The hypotheses proposed in the study are as follows:

a) E-Services significant positive effect on customer trust

b) Customer trust has a significant positive effect on customer commitment

c) E-Services significant positive effect on customer commitment

d) Customer trust significantly mediates the effect of e-services on customer commitment

\section{RESEARCH METHODOLOGY}

The object of this research is the quality of automated services (e-services), customer trust, and customer commitment. This research was conducted on customers of the Bali Regional Development Bank (Bank BPD Bali) in Denpasar City. This study uses two types of data, namely qualitative data and quantitative data. Qualitative data is data that is expressed in the form of words, sentences, and schemas (Sugiyono, 2013, p.23). In this study, qualitative data is the respondent's assessment of the statements submitted in the research questionnaire. Quantitative Data, is data in the form of numbers that can be expressed and measured by calculating or qualitative units that are numbered (Sugiyono, 2013, p. 23). Quantitative data used in this study were the number of customers from Bank BPD Bali in Denpasar City. Sources of data used in this study is primary data sources, namely data obtained directly from customers who are used as research samples. The population in this study were all customers of Bank BPD Bali in Denpasar City. The sample in this study were customers of Bank BPD Bali in Denpasar City who were active for the last 3 years, domiciled in Denpasar City and had a minimum education of high school / equivalent. The determination of the sample in this study used a non-probability sampling method with accidental sampling technique, namely the determination technique sample based on the spontaneity factor. A customer who accidentally meets a researcher and according to the characteristics of the sample can be used as a sample (Sugiyono, 2013, p. 23). The number of respondent samples taken and determined is at least 510 times the number of indicators (Ferdinand, 2013, p. 51). The number of samples in this study were 15 indicators x $6=90$ respondents.

Research variables in this study are divided into three variables, namely:(Al-Hawari, 2011):

1) Independent Variable.

The independent variable in this study is e-Service, with five indicators, namely: 
(1) All needs are available in the electronic menu

(2) It doesn't take long to wait in line

(3) Banks routinely provide customers' personal transaction information

(4) Availability of adequate feedback service

(5) Guaranteed electronic transaction security

2) The Mediation Variable, namely the Trust variable, is reflected by five indicators, namely:

(1) Banks can always be trusted

(2) Banks can be counted on to do what's right

(3) Bank has high integrity

(4) Banks can be relied on to keep promises

(5) Have trust in the bank

3). Dependent Variable

Dependent variable in this research is Customer Loyalty. This variable is reflected

by 3 indicators, namely:

(1) Intends to maintain relationship with BPD Bali bank

(2) The relationship with the bank is given maximum attention

(3) The relationship with the bank is something meaningful

(4) Very committed to the bank

(5) Proud to be a bank customer for financial services

The data analysis technique used in this study is the Partial Least Square (PLS) technique, which was first developed by Herman Wold as a general method for estimating the path model using latent constructs with multiple indicators (Ghozali, 2004,p.17). PLS is a powerful analytical method because it can be applied to all data scales, does not require many assumptions and can also be used for relatively small sample sizes (minimum recommended range from 30 to 100). The reason for using PLS is because it does not assume a certain distribution of data (can be nominal, categorical, ordinal, interval, and ratio). PLS is used to determine the complexity of the relationship between latent variables and their indicators.

\section{RESULTS AND DISCUSSION}

The research instrument test consists of a validity test and a reliability test. Validity test is needed to measure the extent to which the research instrument (questionnaire) is able to measure what it is supposed to measure. An instrument is said to be valid if the correlation coefficient value of the question item with a total score is greater than 0.3 with an error rate (Alpha) below 0.05. Validity test results are presented in Table 1

Table 1 Recapitulation of Research Instrument Validity Test Results for E-Service Variables

\begin{tabular}{clccl}
\hline No & \multicolumn{1}{c}{ Indicator } & $\begin{array}{c}\text { Pearson } \\
\text { Correlation } \\
(\mathrm{r})\end{array}$ & $\begin{array}{c}\text { Sig. }(2- \\
\text { tailed })\end{array}$ & Information \\
\hline 1. & $\begin{array}{l}\text { All needs are available in the } \\
\text { electronic menu }\end{array}$ & 0.852 & 0.000 & Valid \\
2. & $\begin{array}{l}\text { It doesn't take long to wait in line } \\
\text { 3. }\end{array} \quad \begin{array}{l}\text { Banks routinely provide customers' } \\
\text { personal transaction information }\end{array}$ & 0.830 & 0.000 & Valid \\
4. & $\begin{array}{l}\text { Availability of adequate feedback } \\
\text { service }\end{array}$ & 0.925 & 0.000 & Valid \\
5. & $\begin{array}{l}\text { Guaranteed electronic transaction } \\
\text { security }\end{array}$ & 0.842 & 0.000 & Valid \\
\hline
\end{tabular}

Source: Results of data analysis 
Table 1 shows that the research instrument used to measure the E-services variable is valid because all indicators have a correlation value (r) above 0.3 with a significance below 0.05 .

Table 2. Recapitulation of Research Instrument Validity Test Results for Customer Trust

\begin{tabular}{clccc}
\multicolumn{4}{c}{ Variables } \\
\hline No & \multicolumn{1}{c}{ Indicator } & $\begin{array}{c}\text { Pearson } \\
\text { Correlation }\end{array}$ & $\begin{array}{c}\text { Sig. (2- } \\
\text { tailed) }\end{array}$ & Information \\
\hline 1. & Banks can always be trusted & 0.840 & 0.000 & Valid \\
2. & $\begin{array}{l}\text { Banks can be counted on to do } \\
\text { what's right }\end{array}$ & 0.822 & 0.000 & Valid \\
3. $\quad$ Bank has high integrity & 0.812 & 0.000 & Valid \\
4. $\quad \begin{array}{l}\text { Banks can be relied on to keep } \\
\text { promises }\end{array}$ & 0.908 & 0.000 & Valid \\
5. $\quad$ Have trust in the bank & 0.758 & 0.000 & Valid \\
\hline
\end{tabular}

Source: Results of data análisis

Table 2 shows that the research instrument used to measure the customer trust variable is valid because all indicators have a correlation value ( $\mathrm{r}$ ) above 0.3 with a significance below 0.05 .

Table 3. Recapitulation of Research Instrument Validity Test Results for Customer Commitment Variables

\begin{tabular}{|c|c|c|c|c|}
\hline No & Indicator & $\begin{array}{c}\text { Pearson } \\
\text { Correlation }\end{array}$ & $\begin{array}{l}\text { Sig. (2- } \\
\text { tailed) }\end{array}$ & Information \\
\hline 1. & $\begin{array}{l}\text { Intends to maintain relationship with } \\
\text { BPD Bali bank }\end{array}$ & 0.376 & 0.000 & Valid \\
\hline 2. & $\begin{array}{l}\text { The relationship with the bank is given } \\
\text { maximum attention }\end{array}$ & 0.898 & 0.000 & Valid \\
\hline 3. & $\begin{array}{l}\text { The relationship with the bank is } \\
\text { something meaningful }\end{array}$ & 0.939 & 0.000 & Valid \\
\hline 4. & Very committed to the bank & 0.903 & 0.000 & Valid \\
\hline 5. & $\begin{array}{l}\text { Proud to be a bank customer for } \\
\text { financial services }\end{array}$ & 0.841 & 0.000 & Valid \\
\hline
\end{tabular}

Source: Results of data análisis

Table 3 shows that the research instrument used to measure the Customer Commitment variable is valid because all indicators have a correlation value (r) above 0.3 with a significance below 0.05 . Reliability test is used to determine the unidimensionality of statement items on the latent variables studied (service quality, product knowledge, and loyalty). The test used in this case is the Cronbach Alpha value. The instrument is said to be reliable if the Cronbach's Alpha value is greater than or equal to 0.60 (Ghozali, 2004,p.17). The recapitulation of the research instrument reliability test can be seen in Table 4 .

Table 4. Recapitulation of Research Instruments Reliability Test

\begin{tabular}{|c|c|c|c|}
\hline \multicolumn{4}{|c|}{ Cronbach's } \\
\hline No & Variable & Alpha & Information \\
\hline 1 & E-Services & 0.895 & Reliable \\
\hline
\end{tabular}




\begin{tabular}{clll}
2 & Customer Trust & 0.878 & Reliable \\
3 & Customer Commitment & 0.913 & Reliable \\
\hline Source: Results of data analysis &
\end{tabular}

Table 4 shows that the Cronbach's Alpha value for each variable is greater than 0.60 so that it has fulfilled the reliability or reliability requirements.

\section{PLS analysis results}

1) Assessing the outer model or measurement model

Before discussing the significance of the influence of each independent variable on the dependent variable, the measurement model is first measured. PLS has two criteria to assess the outer model, namely convergent validity and discriminant validity. Convergent validity is measured based on average variance extracted (AVE) and composite reliability (Ghozali, 2008,p.17).The use of data analysis techniques using Smart PLS, the outer model is assessed by looking at convergent validity (the magnitude of the loading factor for each construct). This study uses a minimum loading factor limit of 0.5 .

Table 5. Outer Loadings

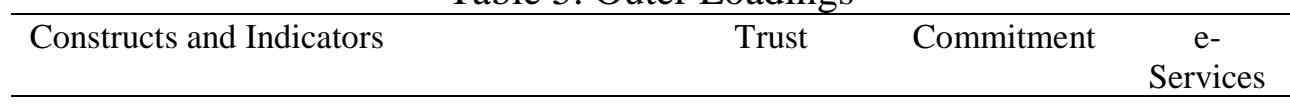

\section{Trust Construct:}

a) Banks can always be trusted 0.810

b) Banks can be counted on to do what's $\quad 0.849$ right

c) Bank has high integrity $\quad 0.856$

d) Banks can be relied on to keep 0.836

promises
Have trust in the bank $\quad 0.810$

\section{E-Service Construction}

a) All needs are available in the electronic menu

b) It doesn't take long to wait in line personal transaction information

d) Availability of adequate feedback

e) Guaranteed electronic transaction security

\section{Customer Commitment Construct}
a) Intends to maintain relationship with BPD Bali bank
b) The relationship with the bank is given maximum attention
c) The relationship with the bank is
e) Proud to be a bank customer for

The processing results are as shown in Table 5 which shows that the value of the outer model has met the convergent validity criteria where all indicators have a loading factor above 0.50 . It can be concluded that the construct has good convergent validity. 
2) Discriminant validity

Discriminant validityof the measurement model with reflective indicators assessed on the basis of crossloading. measurement with the construct. If the crossloading value of an indicator has the largest value in the construct it reflects, then the indicator is declared valid as a reflection of the construct.

Table 6. Cross Loadings

\begin{tabular}{llcc}
\hline \multicolumn{1}{c}{ Constructs and Indicators } & Trust & Commitment & $\begin{array}{c}\text { e- } \\
\text { Services }\end{array}$ \\
\hline $\begin{array}{l}\text { Trust Construct: } \\
\text { a) Banks can always be trusted }\end{array}$ & 0.810 & 0.581 & 0.676 \\
b) Banks can be counted on to do what's & 0.849 & 0.706 & 0.784 \\
$\quad$ right & 0.856 & 0.649 & 0.708 \\
c) Bank has high integrity & 0.836 & 0.626 & 0.629 \\
d) Banks can be relied on to keep promises & 0.810 & 0.563 & 0.640 \\
e) Have trust in the bank & & & \\
E-Service Construction & 0.602 & 0.599 & 0.823 \\
a) All needs are available in the electronic & & & \\
$\quad$ menu & 0.674 & 0.608 & 0.850 \\
b) It doesn't take long to wait in line & 0.737 & 0.669 & 0.890 \\
c) Banks routinely provide customers' & & & 0.771 \\
personal transaction information & 0.688 & 0.586 & 0.831 \\
d) Availability of adequate feedback service \\
e) Guaranteed electronic transaction security
\end{tabular}

The data in Table 6 explains that the cross loading value indicates a good discriminant validity. This can be seen from the crossloading indicator value to the construct (loading factor) which is higher than the crossloading indicator value with other constructs.

3) Model reliability test

The reliability of a construct can be assessed from composite reliability which serves to measure internal consistency whose value must be above 0.60 and compare the AVE root with correlations between constructs with a value that must be above 0.50 (Ghozali, 2008,p.17).

Table 7 Composite Reliability Value

\begin{tabular}{lc}
\hline Construct & Composite Reliability \\
\hline Trust & 0.919 \\
Commitment & 0.936 \\
\hline
\end{tabular}




\begin{tabular}{ll}
\hline e-Services & 0.919 \\
\hline Source: Results of data analysis &
\end{tabular}

Table 7 shows that the composite reliability value of all constructs, which is above 0.60 , has met the reliable criteria. Another way to test reliability is to compare the root value of the Average Variance Extracted AVE) of each construct with the correlation between the constructs and other constructs.

Table 7 AVE Value and AVE . Root

\begin{tabular}{lcc}
\hline Construct & $\begin{array}{c}\text { Average Variance } \\
\text { Extracted (AVE) }\end{array}$ & AVE . root \\
\hline Trust & 0.693 & 0.832 \\
Commitment & 0.745 & 0.863 \\
e-Services & 0.695 & 0.834 \\
\hline
\end{tabular}

Source: Data analysis results

The AVE roots in Table 7 will be compared with the correlation values between independent variables as shown in Table 8 .

Table 8. Correlation between Latent Variables

\begin{tabular}{lrrr}
\hline \multicolumn{1}{c}{ Construct } & Trust & Commitment & e-Services \\
& & & \\
\hline Trust & 1,000 & 0.754 & 0.830 \\
Commitment & 0.754 & 1,000 & 0.748 \\
e-Services & 0.830 & 0.748 & 1,000 \\
\hline
\end{tabular}

Source: Results of data analysis

Table 8 shows that the AVE root of each construct is greater than the correlation value between constructs, so it can be said that the data is reliable.

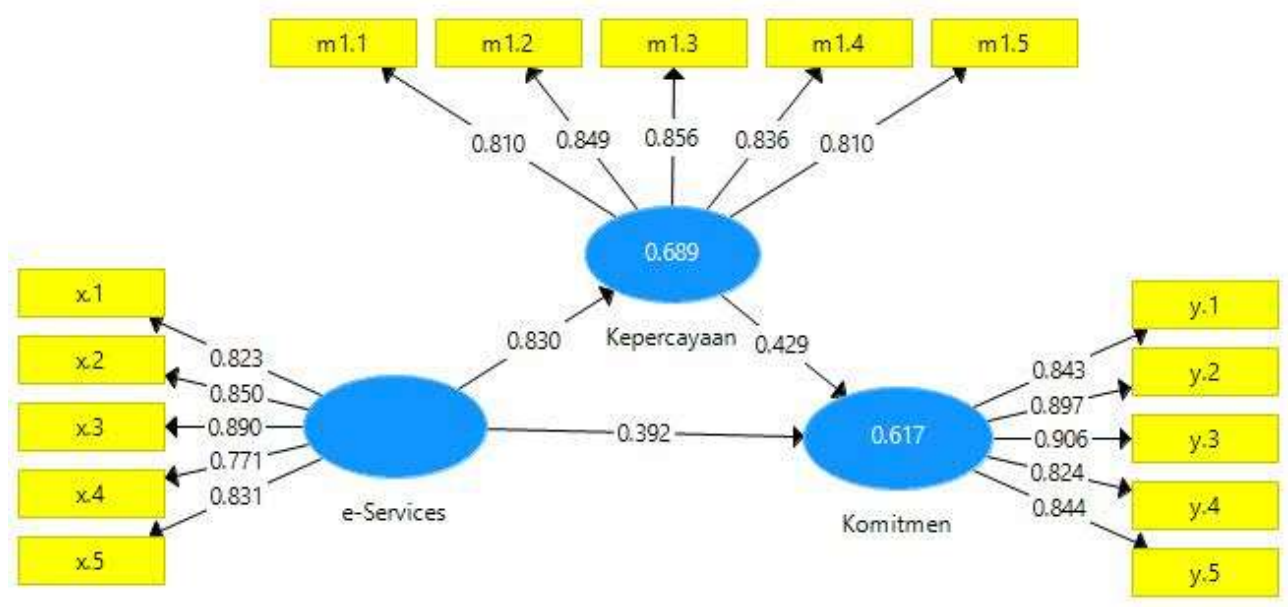




\section{Chart 1 Diagram of the Effect of E-Services on Customer Commitment Mediated by the Customer Trust Variable.}

Source: Results of data analysis

4) Structural model testing (inner model)

Inner model used to describe the relationship between constructs based on substantive theory. In assessing the model with PLS, it begins by looking at the R-squares for each dependent latent variable. The results of the inner model test can see the relationship between constructs by comparing the significance value and R-square of the research model (Ghozali, 2008, p.17). Based on the analysis, the R-square value of the Customer Trust construct is 0.689 . These results can be interpreted that $68.90 \%$ of the variability of the Trust construct is explained by the E-services variable while the remaining $31.10 \%$ is explained by other constructs. The Customer Commitment construct has an R-Square value of 0.617 which means that $61.7 \%$ of the variance of customer commitment is determined by E-Service and Customer Trust, while the remaining $38.30 \%$ is determined by variables outside the model.

The structural model is called the reflexive model. In this model, there is one exogenous construct, namely E-Services, and two endogenous constructs, namely Customer Trust and Customer Commitment. The three constructs have their respective indicators.

5). Hypothesis test

Hypothesis testing about the direct effect of E-Services on Customer Trust and Customer Commitment inpresent in Table 9.

Table 9 Estimated Result of Direct Effect and P Value

\begin{tabular}{lccc}
\hline \multicolumn{1}{c}{ Relationship between Constructs } & $\begin{array}{c}\text { Original } \\
\text { Sample }(\mathrm{O})\end{array}$ & $\begin{array}{c}\text { T Statistics } \\
(|\mathrm{O} / \mathrm{STDEV}|)\end{array}$ & $P$ Values \\
\hline Trust -> Commitment & 0.429 & 2,285 & 0.023 \\
e-Services -> Trust & 0.830 & 24,890 & 0.000 \\
e-Services -> Commitment & 0.392 & 2,540 & 0.011
\end{tabular}

Source: Results of data analysis

Testing the hypothesis in the PLS method is carried out by using a simulation of each hypothesized relationship, in this case the bootstrap method is carried out on the sample. The bootstrap method also serves to minimize the problem of abnormality in the research data used. In this study, the Alpha value was set at 5\%. All the estimated coefficients in Table 9 have a $p$ value below 0.05 so that they are declared to have a significant effect. Testing of each hypothesis is discussed in the following sub.

a) Hypothesis testing 1 (Effect of E-Services on Customer Trust)

Results The first hypothesis testing shows that E-Services has a positive effect on customer trust. This is indicated by the estimated coefficient value of 0.830 with a $P$ value of 0.000 . The better the E-Services, the higher the customer trust will be. The results of testing this hypothesis indicate that Hypothesis 1 is accepted.

b) Hypothesis testing 2 (The Influence of Customer Trust on Customer Commitment)

Results The second hypothesis testing shows that customer trust has a positive effect on customer commitment. This is indicated by the estimated coefficient value of 0.429 with a $\mathrm{P}$ value of 0.023 . The more customer trust, the higher the customer's commitment. The results of testing this hypothesis indicate that Hypothesis 2 is accepted.

c) Hypothesis testing 3 (Effect of E-Services on Customer Commitment) 
Results The third hypothesis testing shows that E-Services has a positive effect on customer commitment. This is indicated by the estimated coefficient value of 0.392 with a P value of 0.011 . The better the E-Services, the higher the customer commitment. The results of testing this hypothesis indicate that Hypothesis 3 is accepted.

d). Hypothesis testing 4 (Customer Trust mediates the effect of E-Services on Customer commitment)

Results Testing the fourth hypothesis about the role of the customer trust variable in mediating the effect of E-Services on Customer Commitment is presented in Table 10.

Table 10. Indirect effect Effect of E-Services on Customer Commitment through Customer Trust

Table 10 shows that customer trust significantly mediates the effect of E-Services on customer commitment. This is indicated by the estimated indirect effect coefficient value of 0.356 with a $P$ value of 0.024 . The better the E-Services, the higher the customer trust and the impact on increasing customer commitment. The results of testing this hypothesis indicate that Hypothesis 4 is accepted.

\section{Discussion}

The results of the analysis show that E-services have a positive effect on customer trust and also have a positive effect on customer commitment. Customer trust also affects customer commitment. E-services increase the effectiveness and efficiency of services to customers. Customers can quickly settle their financial obligations and do not require much time to process them. This shows that banking institutions are required to always provide quality services so that the trust and commitment of customers will be better. Improving service quality can be done by increasing the dimensions of E-services such as providing more complete transaction menus. Likewise, to increase trust, banks can perform services correctly and in real time.

Similar studies also show appropriate results, such as the effect of service quality on the performance of national and foreign banks(Al-tamimi \& Hussein, 2006). The dimension of technology-based service quality also has an influence on customer loyalty (Ganguli \& Roy, 2011), (Hazra \& Srivastava, 2009), (Al-hawari, 2011). Other research shows that service quality also has a significant positive impact on Word of Mouth as an indicator of customer loyalty(Istri Indriani \& Nurcaya, 2015). Service quality also has a significant positive impact on customer satisfaction at Bank BPD Campem Unud(Permatasari \& Nurcaya, 2014). Service quality also has a significant influence on bank customer loyalty in Rajasthan (Kaura et al., 2015)

\section{CONCLUSION}

E-Services has a positive effect on customer trust and customer commitment. The better the e-services, the higher customer trust will be as well as customer commitment. Customer trust also has a positive effect on customer commitment. The higher the customer trust, the higher the commitment. Likewise, customer trust is proven to mediate the effect of e-services on customer commitment. E-Services will build customer trust which has an impact on increasing customer commitment. Banking institutions can increase customer commitment by 
implementing automated services that are integrated and reliable. The menus in the application provided should be able to meet the needs of customers to conduct transactions comfortably and safely. Further researchers can develop this research on various types of banking businesses and also other businesses that implement services electronically.

\section{REFERENCE}

Abdullah, F., Suhaimi, R., Saban, G., Hamali, J., Teknologi, U., \& Uitm, M. (2011). Bank Service Quality ( BSQ ) Index An indicator of service performance. International Journal of Quality \& Reliability Management, 28(5). 542-555. https://doi.org/10.1108/02656711111132571

Al-hawari, M. A. (2011). Automated service quality as a predictor of customers' commitment A practical study within the UAE retail banking context. Asia Pacific Journal of Marketing and Logistics, 23(3), 346-366. https://doi.org/10.1108/13555851111143259

Al-tamimi, H., \& Hussein, A. (2006). Service Quality \& Bank Performance : A Comparison of the UAE National and Foreign Banks. Finance India, 20(1), 181-196.

Angenu, B. B., Quansah, F., \& Okoe, A. F. (2015). Determinants of Online Banking Adoption among Ghanaian University Students. Journal of Service Science and Management, 08(02), 183-190. https://doi.org/10.4236/jssm.2015.82020

Augusty Ferdinand. (2013). Metode Penelitian Manajemen:Pedoman Penelitian untuk Skripsi, Tesis dan Disertai Ilmu Manajemen. BP. Universitas Diponegoro.

Ganguli, S., \& Roy, S. K. (2011). Generic technology-based service quality dimensions in banking: Impact on customer satisfaction and loyalty. International Journal of Bank Marketing, 29(2), 168-189. https://doi.org/10.1108/02652321111107648

Ghozali, I. (2004). Aplikasi Analisis Multivariate Dengan Program SPSS. BP. Universitas Diponegoro.

Ghozali, I. (2008). Structural Equation Modeling: Metode Alternatif Dengan Partial Least Square. BP. Univerisitas Diponegoro.

Hazra, S. G., \& Srivastava, K. B. L. (2009). Impact of Service Quality on Customer Loyalty, Commitment and Trust in the Indian Banking Sector. The IUP Journal of Marketing Management, VIII(3), 74-95.

Istri Indriani, A. A. ., \& Nurcaya, I. N. (2015). Pengaruh Kualitas Pelayanan Terhadap Word of Mouth Yang Dimediasi Oleh Kepercayaan Pelanggan Pada Pt . Auto Bagus Rent a Car. E-Jurnal Manajemen Universitas Udayana, 4(5), 1301-1321.

Johnston, R., \& Kong, X. (2011). The customer experience : a road-map for improvement. Managing Service Quality, 21(1), 5-24. https://doi.org/10.1108/09604521111100225

Kaura, V., Prasad, C. S. D., \& Sharma, S. (2015). Service quality, service convenience, price and fairness, customer loyalty, and the mediating role of customer satisfaction. Marketing Intelligence and Planning, 33(4), 404-422. https://doi.org/10.1108/IJBM-04-2014-0048

Nurcaya, I. N. (2018). Bunga Rampai Strategi Penguatan LPD di Bali (K. Ardana (ed.); p. 190). Udayana University Press. http://penerbit.unud.ac.id

Parasuraman A., Zeithaml Velarie A., B. L. L. (1985). A Conceptual Model of Service Quality and Its Implications for Future Research. Journal of Marketing, 49, 41-50.

Permatasari, A. A. A. R., \& Nurcaya, I. N. (2014). Pengaruh Kualitas Pelayanan dan Nilai Nasabah terhadap Kepuasan Nasabah pada PT. Bank BPD Capem UNUD. E-Jurnal Manajemen Universitas Udayana, 3(10), 2960-2972. https://ojs.unud.ac.id/index.php/Manajemen/article/view/9368

Sugiyono. (2013). Metode Penelitian Manajemen. Alfabeta, Bandung.

Tjiptono, F. (2012). Pemasaran Strategik. Andi, Yogyakarta.

Valarie, A., \& Leonard, L. (1988). Servqual : A Multiple-Item Scale For Measuring Consumer 
Perc. Journal of Retailing, 64(1), 12-40.

Xu, J. D., Benbasat, I., \& Cenfetelli, R. (2011). The Effects of Service and Consumer Product Knowledge on Online Customer Loyalty. Journal of the Association for Information System, 12(11), 741-766. 